\title{
Optimalisasi Sistem Informasi Perjalanan Dinas Dalam Meningkatkan Efisiensi Biaya Perusahaan
}

\author{
Susan Rachmawati ${ }^{1}$, Tri Retnasari ${ }^{2}$, Sunarto ${ }^{3}$ \\ Address: Universitas Bina Sarana Informatika, Manajemen Keuangan, Indonesia ${ }^{1}$, STMIK Nusa Mandiri, Sistem Informasi, \\ Indonesia², Universitas Gunadarma, Akuntansi, Indonesia ${ }^{3}$ \\ Email: susan.srw@bsi.ac.id ${ }^{1}$, tri.trs@nusamandiri.ac.id ${ }^{2}$, sunarto@staff.gunadarma.ac.id ${ }^{3}$ \\ * Susan Rachmawati
}

\begin{abstract}
Abstrak
Latar Belakang : perjalanan dinas merupakan salah satu biaya yang harus dikeluarkan oleh suatu perusahaan bagi karyawannya yang ingin bekerja di luar kantor. Untuk saat ini perjalanan dinas merupakan biaya yang cukup besar nilainya dan sering terjadi, oleh karena itu perlu adanya sistem informasi yang memudahkan bagi karyawan dalam melaporkan kegiatan yang dilakukan dan biaya yang dikeluarkan begitu juga dengan administrasi dalam mencetak surat dinas perjalanan dinas dan bagian keuangan dalam menghitung besarnya biaya yang dikeluarkan sehingga memudahkan dalam pelaporan keuangan selain itu dengan menggunakan sistem informasi keamanan data lebih terjamin karena tersimpan dalam database dan menghilangkan penginputan ganda karena saat ini untuk pembuatan surat tugas perjalanan dinas, penghitungan biaya sampai dengan memberikan informasi kepada kaaryawan yang akan melakukan perjalanan dinas masih dilakukan secara manual (excel) sehingga menyulitkan dalam pembuatan surat tugas perjalanan dinas sampai dengan penghitungannya dan masih sering terjadinya penghitungan maupun pencatatan ganda serta laporan tidak dapat dilakukan secara real time.

Metode: Metode peneltian yang penulis lakukan dengan analisis deskriptif menggunakan metode studi kasus dan analisa pekerjaan dan aktivitas sedangkan untuk pengembangan system menggunakan unified approach (UA)

Hasil : Dalam sistem informasi ini memiliki alur mulai dari penerimaan SPPS (administrasi), pengajuan SPPD, persetujuan, manajemen keuangan, manajemen kepegawaian sampai dengan pembuatan laporan sehingga telah memenuhi kebutuhan dari user dan diharapkan dengan penggunaan sistem informasi ini dapat meminimalkan biaya yang dikeluarkan karena menghindari kerangkapan data bdan manipulasi data. Kesimpulan: Dapat memudahkan dalam pembuatan surat perintah perjalanan dinas, pengeluaran biaya dapat ditampilkan secara terinci sehingga memudahkan dalam pelaporan perjalanan dinas sehingga diharapkan dapat meningkatkan efisiensi pengeluaran perusahaan.
\end{abstract}

\section{Keywords - Cost, Efficiency, Information, System, SPPD}

\section{Latar Belakang}

Informasi yang benar dengan didukung bukti-bukti yang relevan merupakan suatu hal yang vital dalam suatu organisasi karena dengan adanya informasi tersebut dapat menekan atau meminimalkan biaya yang dikeluarkan perusahaan. Sebagai salah satu contoh biaya perjalanan dinas yangsampai dengan saat ini merupakan salah satu biaya yang nilainya cukup besar dibandingkan biaya yang lainnya sehingga apabila tidak dikelola dengan baik akan membuat overload biaya.

Pengelolaan surat terutama perjalanan dinas akan membantu dalam mempercepat proses kinerja dan mengoptimalisasikan kegiatan yang akan dilakukan serta meminimalkan terjadinya duplikasi data serta arsip yang menumpuk serta mengetahui rincian biaya yang dieluarkan untuksetiap kegitan yang dilakukan selain itu juga dapat digunakan untuk memantau karyawan yang

Program Studi Teknik Informatika

Universitas Prima Indonesia (UNPRI) Medan 
sering ataupun yang belum pernah melakukan perjalanan dinas.

Untuk saat ini proses pengeloaan perjalanan dinas yang banyak terjadi diperusahaan masih dikelola secara sederhana yaitu pencatatan dilakukan secara manual dan dilengkapi dengan microsoft excell untuk pengelolaannya, hal itu kurang mampu menangani kompleksitas dari banyaknya kegiatan perjalanan dinas yang dilakukan begitu juga dengan banyaknya biaya yang haruis dikeluarkan dan dihitung dalam setiap perjalanan dinas yang dilakukan di tahun anggaran

Akibat yang ditimbulkan dengan pengeloaan perjalanan dinas yang dilakukan secara manual diantaranya : adanya kesalahan pencatatan perjalanan dinas dan biaya yang dikeluarkan dalam setiap perjalanan dinas tersebut, adanya bentrok jadwal perjalanan dinas antara satu pegawai dengan pegawai lainnya, terjadinya kerangkapan data pembayaran untuk perjalanan dinas per masing-masing pegawai, kehilangan data dikarenakan penyimpanan data yang tidak baik, kurang mampu melakukan verifikasi data antara dokument dengan biaya yang dikeluarkan dalam perjalanan dinas tersebut.

Oleh karena itu perlu adanya suatu aplikasi terkomputerisasi yang mampu membantu dalam memberikan informasi secara valid dan real time dalam pembuatan surat perjalanan dinas dan rincian biaya perjalanan dinas tersebut sehingga mampu menekan kesenjangan atau kecemburuan diantara pegawai sehingga mampu meningkatkan kinerja pegawai dan menekan biaya yang dikeluarkan perusahaan.

\section{Surat Perintah Perjalanan Dinas (SPPD)}

Surat perintah perjalanan dinas adalah suatu naskah ataupun surat perintah yang diberikan kepada pejabat untuk melakukan perjalanan dinas dan diberikan kepadanya fasilitas dan pembiayaan untuk menunjang perjalanan dinas tersebut. [5]

Perjalanan dinas adalah surat yang diberikan kepada seorang pegawai disebabkan pegawai tersebut melkaukan suatu tugas tertentu untuk kepentingan dinas dan berada di luar daerah dan diberikan fasilitas tertentu. Kegunaan dari surat perjalanan dinas (SPD) pelengkap keternagan bagi si pembawa surat tersebut agar pekerjaannya dapat berjalan sesuai dengan jadwal yang telah ditentukan.[2]

Perjalanan dinas untuk perusahaan yaitu penyusunan perjalanan secara rinci yang memuat didalamnya mengenai rute perjalanan, jenis kendaraan yang digunakan, waktu keberangkatan, waktu kembali, penginapan, dan catatan informasi penting yang erat kaitannnya dengan perjalanan yang dimaksud. [3]
Perjalanan dinas pimpinan dibedakan menjadi:

1. Klasifikasi tujuan dibedakan menjadi perjalanan dinas pimpinan untuk pelaksanaan pengawasan di kantor cabang atau perusahaan cabang, seminardiklat, tender, janji temu, pertemuan/rapat, penjajakan kerjasama, menghadiri acara seremonial ataupun kegiatan sosial

2. Sarana transportasi dibedakan menjadi perjalanan dinas melewati darat, udara dan laut

3. Lamanya waktu dibedakan menjadi perrjalanan dinas dalam 1 hari dan perjalanan dinas lebih dari 1 hari

4. Wilayah Negara tujuan dibedakan menjadi perjalanan dinas dalam negeri dan luar negeri [1]

Perjalanan dinas jabatan dilakukan oleh pelaksana surat perjalanan dinas (SPD) yang dilakukan sesuai dengan perintah atasan pelaksana surat perjalanan (SPD) yang tertuang didalam surat tugas [9]

\section{Prinsip-prinsip dalam melakukan perjalanan dinas} yaitu: [6]

a. Adanya kepastian tidak akan terjadi pelaksanaan perjalanan dinas yang tumpang tindih atau rangkap

b. Tidak terdapat pelaksanaan perjalanan dinas yang dipecah-pecah apabila suau kegiatan dapat dilaksanakan secara sekaligus dengan sasaran peserta, tempat tujuan dan kinerja yang dihasilkan sama,

c. Perjalanan dinas hanya dilaksanakan oleh Pelaksana Perjalanan Dinas yang memang benar-benar

\section{Beberapa pengertian mengenai perjalanan dinas} diantaranya: [8]

a. Perjalanan dinas dalam negeri selanjutnya disebut perjalanan dinas adalah perjalanan ke luar tempat kedudukan yang dilakukan dalam wilayah republik Indonesia untuk kepentingan negara.

b. Perjalanan dinas jabatan adalah perjalanan dinas melewati batas Kota dan/atau dalam Kota dari tempat kedudukan ke tempat yang dituju, melaksanakan tugas, dan kembali ke tempat kedudukan semula di dalam negeri.

c. Perjalanan dinas pindah adalah perjalanan dinas dari tempat kedudukan yang lama ke tempat kedudukan yang baru berdasarkan surat keputusan pindah.

d. Surat perjalanan dinas, selanjutnya disingkat SPD adalah dokumen yang diterbitkan PPK dalam rangka pelaksanaan perjalanan dinas pejabat negara, pegawai negeri, pegawai tidak tetap, dan pihak lain.

e. Pelaksana SPD adalah pejabat negara, pegawai negeri, dan pegawai tidak tetap yang melaksanakan perjalanan dinas. 
f. Kota adalah kota/kabupaten pembagian wilayah administrative di indonesia di bawah provinsi.

\section{Beberapa istilah dalam perjalanan yaitu: [7]}

a. Perjalanan dinas dalam negeri yang selanjutnya disebut perjalanan dinas adalah perjalanan ke luar tempat kedudukan yang dilakukan dalam wilayah republik indonesia untuk kepentingan negara.

b. Perjalanan dinas jabatan adalah perjalanan dinas melewati batas kota dan/atau dalam kota dari tempat kedudukan ke tempat yang dituju, melaksanakan tugas, dan kembali ke tempat kedudukan semula di dalam negeri.

c. Perjalanan dinas pindah adalah perjalanan dinas dari tempat kedudukan yang lama ke tempat kedudukan yang baru berdasarkan surat keputusan pindah.

d. Surat perjalanan dinas yang selanjutnya disingkat spd adalah dokumen yang diterbitkan oleh pejabat pembuat komitmen dalam rangka pelaksanaan perjalanan dinas bagi pejabat negara, pegawai negeri, pegawai tidak tetap, dan pihak lain.

e. Pelaksana SPD adalah pejabat negara, pegawai negeri, dan pegawai tidak tetap yang melaksanakan perjalanan dinas.

f. Lumpsum adalah suatu jumlah uang yang telah dihitung terlebih dahulu (pre-calculated amount) dan dibayarkan sekaligus.

g. Biaya riil adalah biaya yang dikeluarkan sesuai dengan bukti pengeluaran yang sah.

h. Perhitungan rampung adalah perhitungan biaya perjalanan dinas yang dihitung sesuai kebutuhan riil berdasarkan ketentuan yang berlaku.

i. Tempat Kedudukan adalah lokasi kantor/satuan kerja.

j. Tempat tujuan adalah tempat/kota yang menjadi tujuan perjalanan dinas.

\section{Surat Tugas}

Surat tugas merupakan suatu surat perintah yang diberikan dari atasan kepada bawahan untuk melakukan tugas yang dibebankan kepadanya sesuai dengan waktu dan tempat yang telah ditentukan [5]

Fungsi surat tugas diantaranya sebagai bukti surat pengantar bagi seorang pegawai untuk menjalankan tugasnya; wewenang yang dimiliki oleh penerima tugas untuk menjalankan tugas yang dibebankan kepadanya; sebagai bukti bahwa penerima tugas telah menjalankan tugas sesuai surat tugas yang diterimanya [5]

\section{Sistem}

Sistem adalah suatu totalitas himpunan bagianbagian yang satu dengan yang lain berinteraksi untuk mencapai tujuan tertentu [5]

\section{Sistem Informasi}

Sistem informasi adalah suatu sistem buatan manusia yang secara umum terdiri atas sekumpulan komponen berbasis komputer dan manual yang dibuat untuk menghimpun, menyimpan dan mengelola data serta menyediakan informasi keluaran kepada para pemakai. [5]

Informasi akan bermanfaat apabila informasi tersebut dapat mendukung pengambilan keputusan dan andal [4]

\section{Manajemen Sumber Daya Manusia}

Menurut [4] yang dimaksud dengan manajemen sumber daya manusia merupakan salah satu sumber daya yang penting sebagai factor utama untuk diperhatikan dalam organisasi karena menyangkut perilaku manusia yang akan member dampak pada aktivitas organisasi untuk mampu mencapai sutau tujuan organisasi atau keberhasilan suatu organisasi.

\section{Pelatihan}

Pelatihan dan pengembangan adalah proses belajar dan usaha yang dilakukan organisasi untuk meningkatkan keterampilan kerja karyawannya. Pengembangan lebih ditujukan untuk meningkakan kamampuan manajerial sedangkan pelatihan lebih ditujuan untuk meningkatkan keterampilan teknis [10]

\section{UML}

UML digunakan untuk menggambarkan perancangan awal dari sistem yang akan dibangun [11].

Uml memiliki banyak permodalan tetapi hanya beberapa yang digunakan untuk pembahasan

\section{Metode}

Metode penelitian yang penulis lakukan dalam penelitian ini yaitu:

a. Metode deskriptif dengan cara:

a) Penelitian studi kasus yaitu perjalanan dinas yang sering dilakukan hampir disetiap organisasi/perusahaan

b) Penelitian analisa pekerjaan dan aktivitas yaitu dengan mengamati kelakukan-kelakuan yang dilakukan oleh pekerja dalam melakukan perjalanan dinas (mulai dari keberangkatan sampai dengan pelaporan biaya yang dikeluarkan untuk perjalanan dinas)

b. Metode pengembangan sistem

Metode yang digunakan dalam pengembangan berorientasi objek adalah Unified Approach (UA) yang merupakan penggabungan antara proses dan metodologi yang telah ada dengan menggunakan Unifield Modelling Languange (UML) sebagai standar permodelannya 


\section{Hasil}

Dalam perencanaan, penyusunan dan pelaporan anggaran perjalanan dinas merupakan suatu hal yang sangat penting untuk mengetahui cash flow perusahaan oleh karena itu perlu adanya data yang valid (biaya yang dianggarkan terkadang berbeda dengan biaya riil yang dikeluarkan) diantaranya berapa biaya yang dikeluarkan secara riil diantaranya biaya akomodasi, penginapan, makan dsb, perjalanan dinas sebaiknya dilaporkan maksimal satu minggu setelah dilakukannya perjalanan dinas tersebut tetapi kadang kala pelaporan tidak dilakukan sampai dengan perjalanan dinas berikutnya, sulitnya dalam menghitung biaya perjalanan dinas yang dikeluarkan secara real time dan tepat guna, hal tersebut mendorong perlu adanya suatu sistem informasi yang dapat digunakan untuk memudahkan perencanaan, perhitungan sampai dengan pelaporan perjalanan dinas yang dilakukan.

Berikut ini tahapan yang dilakukan dalam penelitian ini yaitu :

\section{A. Analisis Kebutuhan}

Saat ini karyawan mengajukan permintaan dan pencatatan perjalanan dinas sesuai ketentuan institusi secara manual ke supervisor (bagian yang ditunjuk oleh institusi) dan bagian keuangan akan melakukan pembayaran perjalanan dinas secara manual (sesuai ketentuan yang ditetapkan institusi) sedangkan dengan penggunaan sistem maka sistem akan mampu mendukung karyawan dalam mengajukan permintaan perjalanan dinas dan pencatatan perjalanan dinas dan mampu menentukan cara pembayaran dan cara melakukan perjalanan dinas

\section{B. Use Case}

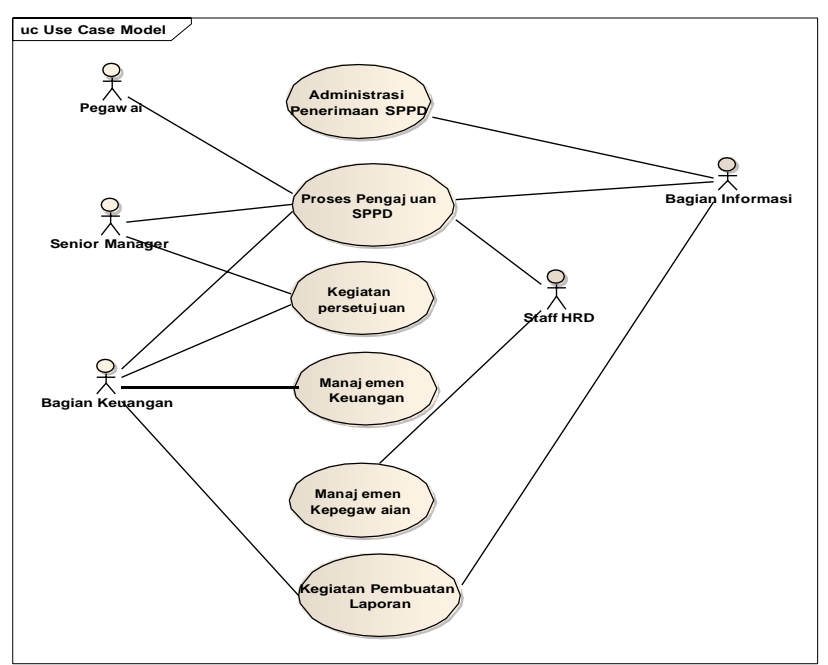

Gambar 1 Use Case

\section{Entity Relation Diagram (ERD)}

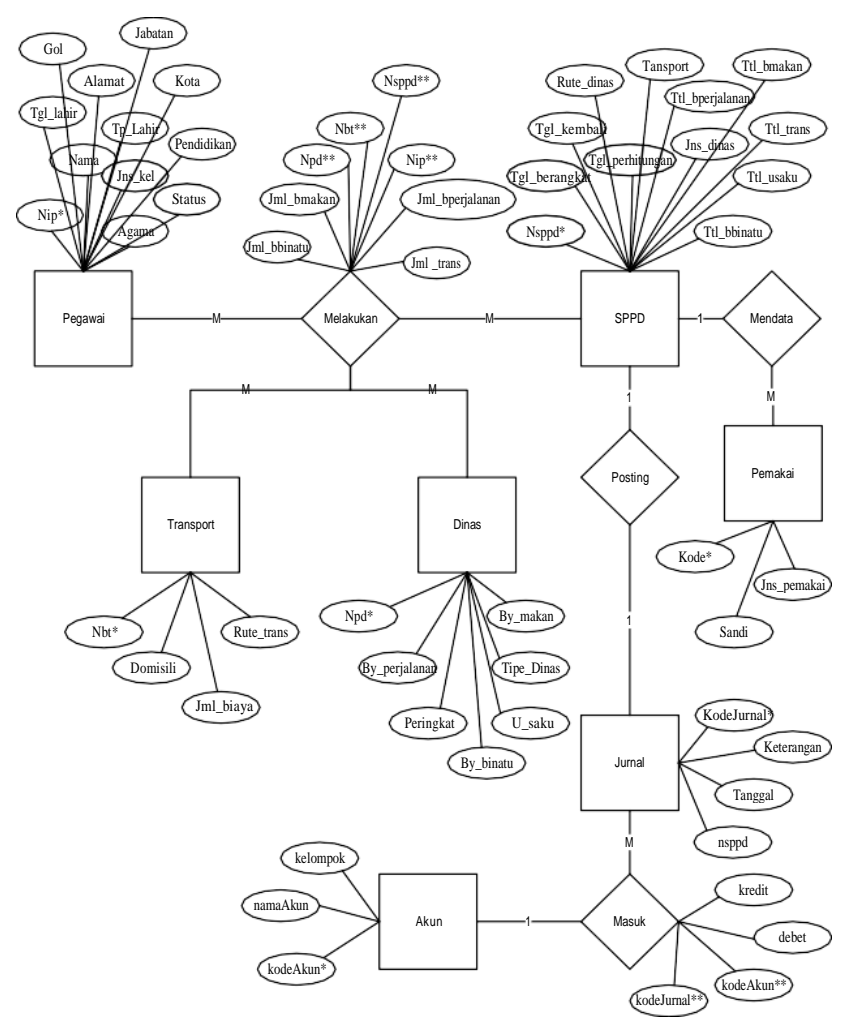

Gambar 2 Entity Relation Diagram (ERD)

D. Logical Record Structure (LRS)

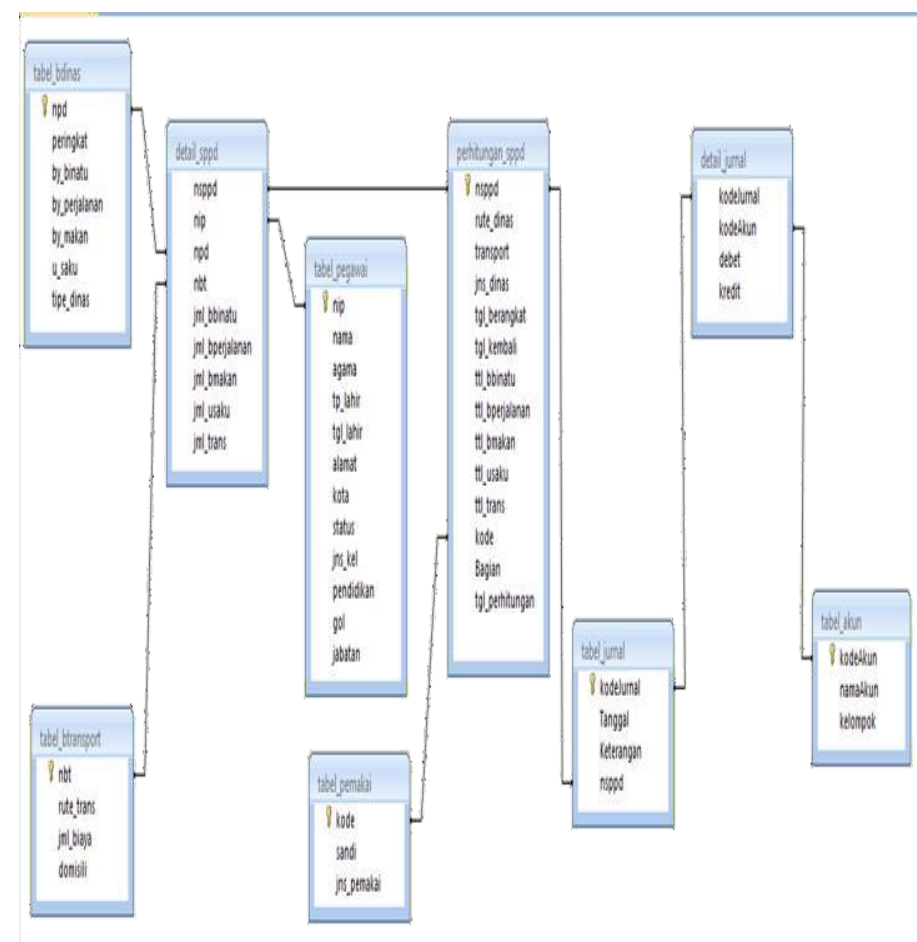

Gambar 3 Logical Record Structure (LRS)

Program Studi Teknik Informatika 


\section{E. Rancangan User Interface}

a. Log in

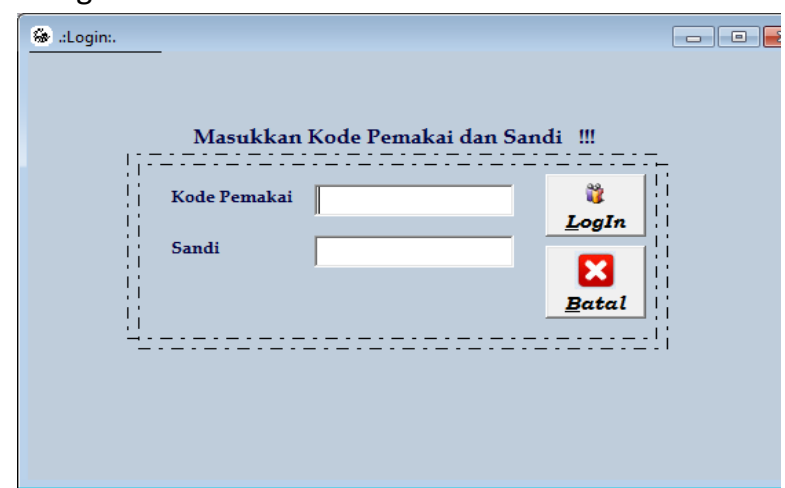

Gambar 4 Tampilan Menu Log In Admin

\section{b. Menu Utama}

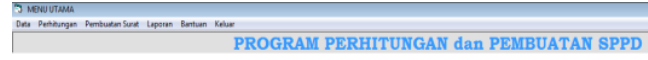

Gambar 5 Tampilan Menu Utama

\section{c. Form Data Pegawai}

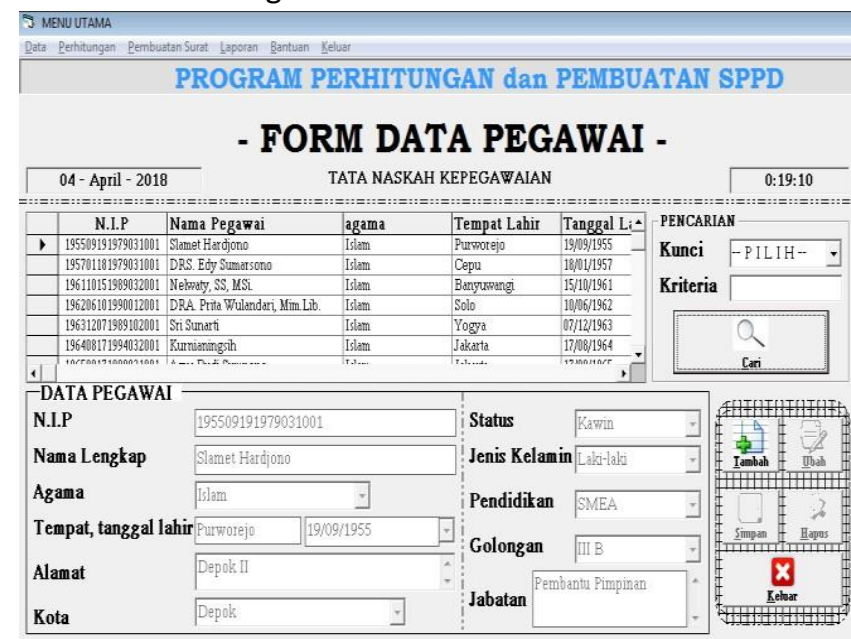

Gambar 6 Tampilan Form Data Pegawai d. Form Data Fasilitas Biaya Dinas

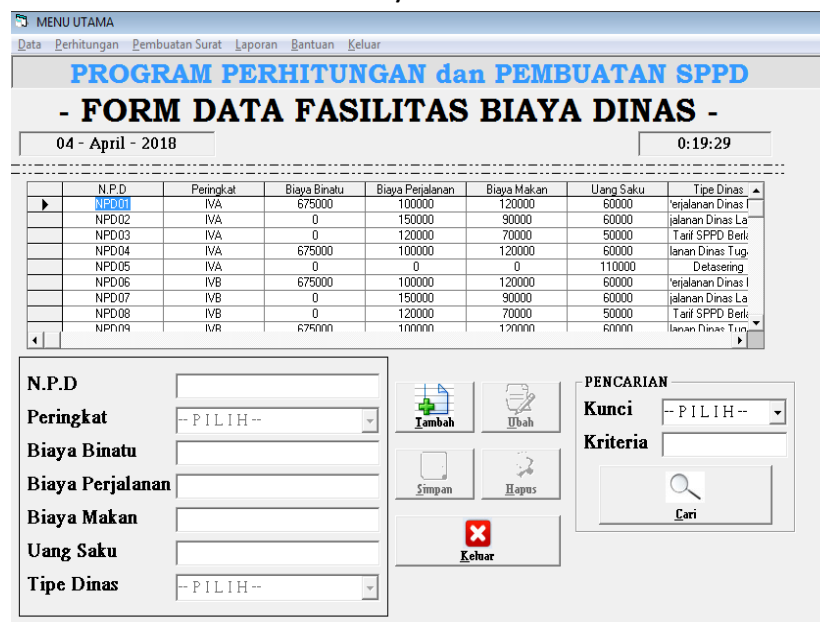

Gambar 7 Tampilan Form Data Fasilitas Biaya Dinas

e. Form Data Transport

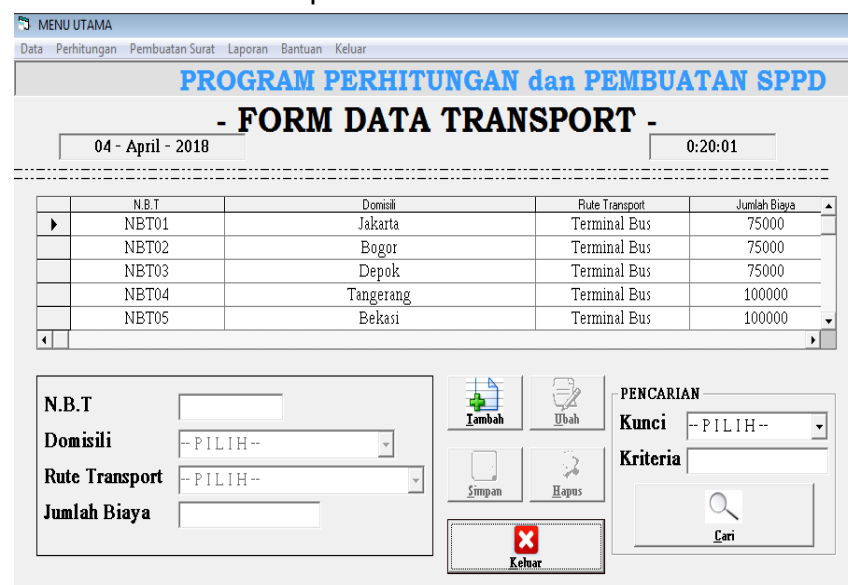

Gambar 8 Tampilan Form Data Transport

f. Form Perhitungan SPPD

PROGRAM PERHITUNGAN dan PEMBUATAN SPPD

- FORM PERHITUNGAN SPPD -

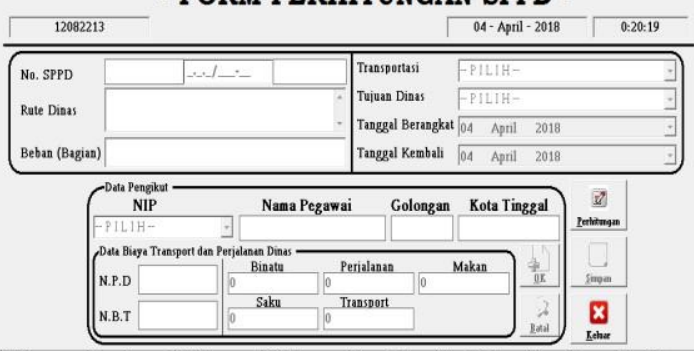

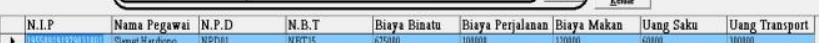

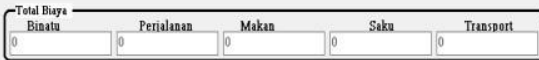

Gambar 9 Tampilan Form Perhitungan SPPD

Program Studi Teknik Informatika

Universitas Prima Indonesia (UNPRI) Medan 
g. Laporan

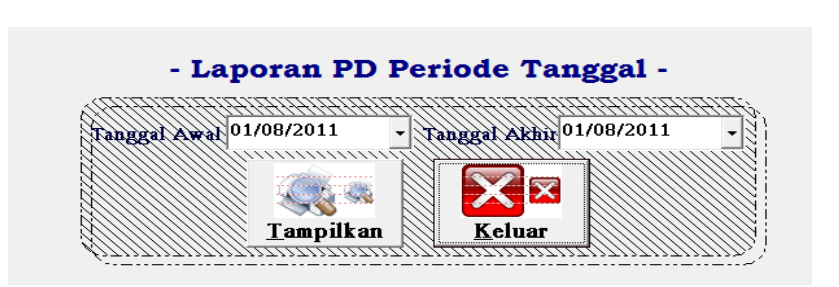

Gambar 10 Tampilan Menu Laporan

\section{LAPORA BIAYA PRRALAGAN DIMS}

\begin{tabular}{|c|c|c|c|c|}
\hline NSPPD & 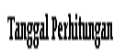 & II legawid & Bigigan & \\
\hline 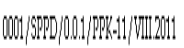 & $8 / 11122111$. & 11111111111111111. & Kupporraien & \\
\hline Jenin Dintws & Rutedings & Thaspont & 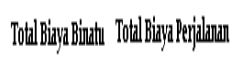 & 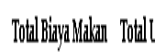 \\
\hline 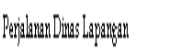 & 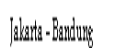 & Teminul $30:$ & 20000 & 190000 \\
\hline
\end{tabular}

\begin{tabular}{|c|c|c|}
\hline MSPDD & 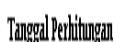 & II propyid \\
\hline 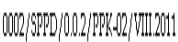 & 8):11:2011. & 1 \\
\hline
\end{tabular}

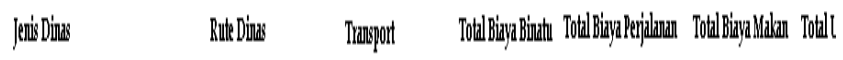

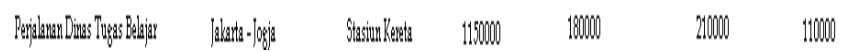

Gambar 11 Tampilan Laporan Biaya Perjalanan Dinas

\section{SURAT PERITIAH PERULAMAI DIIMS}

Pejabat yang berwenang memberituzasiperintah perijalanan dinas sebagai beriliut:

\begin{tabular}{|c|c|c|c|}
\hline N.LP & Nama Pegazai & Jabatan & $\begin{array}{l}\text { Kategoril } \\
\text { Golongan }\end{array}$ \\
\hline 186012061994003201 & Ester Ginting,S.Sos. & Pustakawan Pettama & $\mathbb{I} A$ \\
\hline 19600817199001001 & Agus Budi Sumpeno & Pelaksana & $\mathbb{I B}$ \\
\hline 186312001196910201 & StiGunati & Pelaksana & IID \\
\hline
\end{tabular}

\begin{tabular}{|c|c|c|c|c|}
\hline \multicolumn{5}{|l|}{ Keterangan: } \\
\hline Tanggal Berangkat & Tanggal Kembali & Transpootasi & Jenis Perjalanan Dinas & Biaya perjalanan atas beban \\
\hline 12 Agustus 2011 & 13 Agustus 2011 & Stasiun Kereta & Perjalanan Dinas & Bagian Kepegawaian \\
\hline
\end{tabular}

Gambar 12 Tampilan Surat Perintah Perjalanan Dinas

Program Studi Teknik Informatika

Universitas Prima Indonesia (UNPRI) Medan

$\begin{array}{ll}\text { Jln Salemba Raya No. 28A } & \text { Beban MAK : Bagian Kepegawaian } \\ \text { Jakarta } & \text { Tahun Anggaran : 8/122011 }\end{array}$

\section{K W I T A N S I}

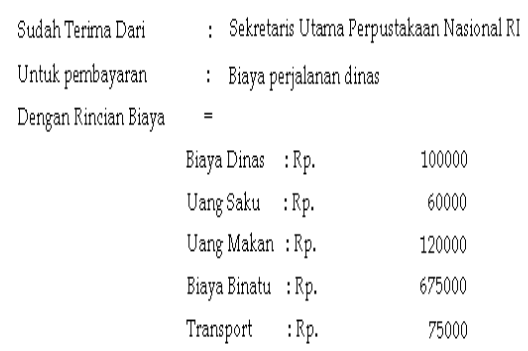

Berdasarkan SPPD Nomor : 0003/SPPD/0.03/PPK-03/VIII.2011

Untuk perjalanan dinas dari: Jakarta- Jogja

Setuju dibayar:

Lunas dibayar:

Gambar 13 Tampilan Kwitansi

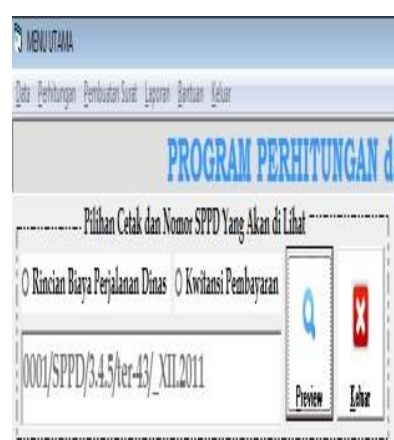

Gambar 14 Tampilan Menu Cetak

Jln. Salemba Raya No. $28 \mathrm{~A}$, Nomor : 0003/SPPD/0.0.3/PPK-03/VII Rute Dinas : Jakarta-Jogja

RINCIAN BIAYA PERJALANAN DINAS

\begin{tabular}{|c|l|r|r|}
\hline \hline Nomor & \multicolumn{1}{|c|}{ Perincian Biaya } & Jumlah & Keterangan \\
\hline 1. & $\begin{array}{l}\text { Biaya Dinas } \\
\text { Tanggal Berangkat: 12 Agustus 2011 } \\
\text { Tanggal Kembali : 13 Agustus 2011 }\end{array}$ & Rp340.000,00 & Stasiun Kereta \\
2. & Uang Saku & Rp160.000,00 & \\
3. & Uang Makan & Rp260.000,00 & \\
4. & Biaya Binatu & Rp675.000,00 & \\
5. & Ongkos Transport & Rp225.000,00 & \\
\hline
\end{tabular}

Gambar 15 Tampilan Rincian Biaya Perjalanan Dinas 


\section{F. Testing}

Tabel 1 Hasil Pengujian Black BoxTesting Form Login admin

\begin{tabular}{|c|c|c|c|c|c|}
\hline \multicolumn{6}{|c|}{ Hasil Pengujian Black Box Testing Form Login User } \\
\hline $\begin{array}{l}\mathbf{N} \\
\mathbf{0}\end{array}$ & $\begin{array}{l}\text { Skenario } \\
\text { Pengujian }\end{array}$ & Test Case & $\begin{array}{c}\text { Hasil Yang } \\
\text { Diharapka } \\
\mathrm{n}\end{array}$ & $\begin{array}{c}\text { Hasil } \\
\text { Pengujia } \\
\mathrm{n}\end{array}$ & $\begin{array}{c}\text { Kesimp } \\
\text { ulan }\end{array}$ \\
\hline 1. & $\begin{array}{l}\text { Mengosong } \\
\text { kan semua } \\
\text { isian data } \\
\text { saat login } \\
\text { user. }\end{array}$ & $\begin{array}{c}\text { Username } \\
\text { : (kosong) } \\
\text { Password: } \\
\text { (kosong) }\end{array}$ & $\begin{array}{c}\text { Sistem } \\
\text { akan } \\
\text { menolak } \\
\text { akses } \\
\text { login. }\end{array}$ & $\begin{array}{c}\text { Sesuai } \\
\text { harapan }\end{array}$ & Valid \\
\hline 2. & $\begin{array}{c}\text { Hanya } \\
\text { mengisi } \\
\text { username } \\
\text { dan } \\
\text { mengosong } \\
\text { kan } \\
\text { password. }\end{array}$ & $\begin{array}{l}\text { Username } \\
\text { : usr001 } \\
\text { Password: } \\
\text { (kosong) }\end{array}$ & $\begin{array}{c}\text { Sistem } \\
\text { akan } \\
\text { menolak } \\
\text { akses } \\
\text { login. }\end{array}$ & $\begin{array}{c}\text { Sesuai } \\
\text { harapan }\end{array}$ & Valid \\
\hline 3. & $\begin{array}{c}\text { Hanya } \\
\text { mengisi } \\
\text { password } \\
\text { dan } \\
\text { mengosong } \\
\text { kan } \\
\text { username. }\end{array}$ & $\begin{array}{l}\text { Username } \\
\text { : (kosong) } \\
\text { Password: } \\
123456\end{array}$ & $\begin{array}{c}\text { Sistem } \\
\text { akan } \\
\text { menolak } \\
\text { akses } \\
\text { login. }\end{array}$ & $\begin{array}{c}\text { Sesuai } \\
\text { harapan }\end{array}$ & Valid \\
\hline 4. & $\begin{array}{c}\text { Menginput } \\
\text { kan dengan } \\
\text { kondisi } \\
\text { salah satu } \\
\text { data benar, } \\
\text { dan satu } \\
\text { lagi salah. }\end{array}$ & $\begin{array}{l}\text { Username } \\
\text { : (benar) } \\
\text { Password: } \\
\text { (salah) }\end{array}$ & $\begin{array}{c}\text { Sistem } \\
\text { akan } \\
\text { menolak } \\
\text { akses } \\
\text { login. }\end{array}$ & $\begin{array}{c}\text { Sesuai } \\
\text { harapan }\end{array}$ & Valid \\
\hline & & $\begin{array}{l}\text { Username } \\
: \text { (benar) }\end{array}$ & $\begin{array}{c}\text { Sistem } \\
\text { menerima }\end{array}$ & & \\
\hline 5. & $\begin{array}{l}\text { Menginput } \\
\text { kan dengan } \\
\text { data login } \\
\text { yang benar. }\end{array}$ & $\begin{array}{l}\text { Password: } \\
\text { (benar) }\end{array}$ & $\begin{array}{c}\text { akses } \\
\text { login } \\
\text { kemudian } \\
\text { langsung } \\
\text { masuk ke } \\
\text { beranda } \\
\end{array}$ & $\begin{array}{l}\text { Sesuai } \\
\text { harapan }\end{array}$ & Valid \\
\hline \multicolumn{6}{|c|}{ Hasil Pengujian Black BoxTesting Form Perhitungan SPPD } \\
\hline $\begin{array}{l}\mathbf{N} \\
\mathbf{0}\end{array}$ & $\begin{array}{l}\text { Skenario } \\
\text { Pengujian }\end{array}$ & Test Case & $\begin{array}{c}\text { Hasil Yang } \\
\text { Diharapka } \\
\mathrm{n}\end{array}$ & $\begin{array}{c}\text { Hasil } \\
\text { Pengujia } \\
\mathrm{n}\end{array}$ & $\begin{array}{c}\text { Kesimp } \\
\text { ulan }\end{array}$ \\
\hline 1. & $\begin{array}{l}\text { Mengosong } \\
\text { kan semua } \\
\text { textbox }\end{array}$ & $\begin{array}{c}\text { No. SPPD : } \\
\text { (kosong) } \\
\text { Rute } \\
\text { Dinas : } \\
\text { (kosong) } \\
\text { Tanggal } \\
\text { Berangkat } \\
\text { : (kosong) } \\
\text { Tanggal } \\
\text { Kembali : } \\
\text { (kosong) } \\
\text { Transport } \\
\text { asi : } \\
\text { (kosong) } \\
\text { Tujuan } \\
\text { Dinas: } \\
\text { (kosong) } \\
\text { Data }\end{array}$ & $\begin{array}{c}\text { Akan ada } \\
\text { notifikasi } \\
\text { "Fill out } \\
\text { this field" }\end{array}$ & $\begin{array}{c}\text { Sesuai } \\
\text { Harapan }\end{array}$ & Valid \\
\hline
\end{tabular}

\begin{tabular}{|c|c|c|c|c|c|} 
& $\begin{array}{c}\text { Pengikut : } \\
\text { (kosong) } \\
\text { Data Biaya } \\
\text { Transport } \\
\text { (kosong) }\end{array}$ & & & \\
\hline 2. & $\begin{array}{c}\text { Mengisi } \\
\text { manual } \\
\text { kolom } \\
\text { Nominal } \\
\text { Data Biaya }\end{array}$ & $\begin{array}{c}\text { Data Biaya } \\
: 10000\end{array}$ & $\begin{array}{c}\text { Tidak } \\
\text { dapat diisi } \\
\text { secara } \\
\text { manual }\end{array}$ & $\begin{array}{c}\text { Sesuai } \\
\text { Harapan }\end{array}$ & Valid \\
\hline 3. & $\begin{array}{c}\text { Mengisi } \\
\text { Nominal } \\
\text { Alokasi } \\
\text { dengan } \\
\text { huruf }\end{array}$ & $\begin{array}{c}\text { Nominal } \\
\text { Alokasi : } \\
\text { ABCDE }\end{array}$ & $\begin{array}{c}\text { Tidak } \\
\text { dapat diisi } \\
\text { dengan } \\
\text { huruf, } \\
\text { hanya } \\
\text { dengan } \\
\text { angka }\end{array}$ & $\begin{array}{c}\text { Sesuai } \\
\text { Harapan }\end{array}$ & Valid \\
& \multicolumn{2}{|c|}{} & \\
\hline
\end{tabular}

Tabel 2 Dokumen Data Transport

\begin{tabular}{|c|c|c|c|c|c|}
\hline \multirow{2}{*}{ No } & \multirow{2}{*}{$\begin{array}{l}\text { Fasilitas } \\
\text { Perjalanan }\end{array}$} & \multicolumn{4}{|c|}{ Peringkat Jabatan Pegawai (Golongan) } \\
\hline & & 1 & II & III & IV \\
\hline 1. & \multicolumn{5}{|c|}{ Perjalanan Dinas Biasa } \\
\hline & $\begin{array}{l}\text { a. Biaya } \\
\text { Penginapa } \\
\text { n dan } \\
\text { Binatu }\end{array}$ & 400.000 & 475.000 & 550.000 & 675.000 \\
\hline & $\begin{array}{l}\text { b. Biaya } \\
\text { Perjalanan }\end{array}$ & 70.000 & 80.000 & 90.000 & 100.000 \\
\hline & $\begin{array}{l}\text { c. Biaya } \\
\text { Makan }\end{array}$ & 75.000 & 90.000 & 100.000 & 120.000 \\
\hline & d. Uang Saku & 45.000 & 50.000 & 55.000 & 60.000 \\
\hline 2. & \multicolumn{5}{|c|}{ Perjalanan Dinas Lapangan } \\
\hline & $\begin{array}{l}\text { a. Uang } \\
\text { Lapangan }\end{array}$ & 100.000 & 120.000 & 140.000 & 150.000 \\
\hline & $\begin{array}{l}\text { b. Biaya } \\
\text { Makan }\end{array}$ & 60.000 & 70.000 & 80.000 & 90.000 \\
\hline & c. Uang Saku & 45.000 & 50.000 & 55.000 & 60.000 \\
\hline 3. & \multicolumn{5}{|c|}{ Tarif SPPD Berlayar } \\
\hline & $\begin{array}{l}\text { a. Uang } \\
\text { Berlayar }\end{array}$ & - & - & 100.000 & 120.000 \\
\hline & $\begin{array}{l}\text { b. Biaya } \\
\text { Makan }\end{array}$ & - & - & 60.000 & 70.000 \\
\hline & c. Uang Saku & - & - & 45.000 & 50.000 \\
\hline 4. & \multicolumn{5}{|c|}{\begin{tabular}{|l|} 
Perjalanan Dinas Tugas Belajar \\
\end{tabular}} \\
\hline & $\begin{array}{l}\text { a. Biaya } \\
\text { Penginapa } \\
\text { n dan } \\
\text { Binatu }\end{array}$ & 400.000 & 475.000 & 550.000 & 675.000 \\
\hline & $\begin{array}{l}\text { b. Biaya } \\
\text { Perjalanan }\end{array}$ & 70.000 & 80.000 & 90.000 & 100.000 \\
\hline & $\begin{array}{l}\text { c. Biaya } \\
\text { Makan }\end{array}$ & 75.000 & 90.000 & 100.000 & 120.000 \\
\hline & d. Uang Saku & 45.000 & 50.000 & 55.000 & 60.000 \\
\hline 5. & \multicolumn{5}{|c|}{ Detasering } \\
\hline & Uang Saku & 90.000 & 100.000 & 105.000 & 110.000 \\
\hline
\end{tabular}

Program Studi Teknik Informatika 


\begin{tabular}{|c|c|c|}
\hline \multirow{2}{*}{ Rute Transport } & Domisili & \multirow{2}{*}{ Biaya } \\
\hline \multirow{2}{*}{ Terminal Bus/Stasiun Kereta } & Jakarta/Bogor/Depok & 75.000 \\
\cline { 2 - 3 } & Tangerang/Bekasi & 100.000 \\
\cline { 2 - 3 } & Luar JABODETABEK & 150.000 \\
\hline \multirow{3}{*}{ Bandara Soekarno Hatta } & Jangerang/Bekasi & \\
\cline { 2 - 3 } & Bogor/Depok & 300.000 \\
\cline { 2 - 3 } & Luar JABODETABEK & - \\
\hline \multirow{3}{*}{ Bandara/pelabuhan lain di } & Tangerang/Bekasi & 150.000 \\
\cline { 2 - 3 } Indonesia & Bogor/Depok & 200.000 \\
\cline { 2 - 3 } & Luar JABODETABEK & 300.000 \\
\hline
\end{tabular}

\section{Kesimpulan}

Berdasarkan tahapan penelitian yang telah dilakukan dalam pengembangan aplikasi surat perintah perjalanan dinas dan rincian biaya perjalanan dinas, maka dapat di tarik kesimpulan diantaranya:

a. Mempermudah dalam pembuatan surat perintah perjalanan dinas,

b. Pengeluaran biaya perjalanan dinas telah ditampilkan secara terinci sehingga memudahkan dalam pelaporan perjalanan dinas,

c. Meminimalkan duplikasi data karena data tersimpan dalam database sehingga efisiensi biaya tercapai,

d. Memudahkan dalam perencanaan perjalanan dinas

\section{Acknowledgement}

Penulis mengucapkan banyak terima kasih kepada institusi Universitas Bina Sarana Informatika, STMIK Nusa Mandiri, Universitas Gunadarma atas dukungannya secara moril sehingga terselesaikannya penelitian ini

\section{References}

(Book style)

[1] Hadi. Sumarto dan Lukas. Dwiantara, Sekretaris Profesional; Yogyakarta: Kanisius, 2000, pp.134.

[2] Supardjati, dkk, Administrasi Perkantoran Surat Menyurat Dalam Perkantoran; Yogyakarta: Kanisius, 2000, pp.72.

[3] Ida. Nuraida, Manajemen Administrasi Perkantoran; Yogyakarta: Kanisius, 2008, pp.163.
[4] Fadila. Ariesta, "Pengaruh Kualitas Sumberdaya Manusia, Pemanfaatan Teknologi Informasi dan Pengendalian Intern Akuntansi Terhadap Nilai Informasi Pelaporan Keuangan Pemerintah Daerah. Dissertation, Dept. Ekonomi., Universitas Negeri Padang, 2013.

[5] Ibnu. Kasir, "Perancangan dan Pembuatan Sistem Informasi Online Surat Perintah Perjalanan Dinas Pada Kantor Biro Humas Sekda Aceh". Dissertation, Dept. Manajemen Informatika, STMIK U'Budiyah Indonesia, 2014.

\section{(Handbook style)}

[6] Permenlu Nomor. 3 Petunjuk Pelaksanaan Perjalanan Dinas Dalam Negeri dan Luar Negeri Pada Kementerian Luar Negeri, 2018, pp. 1-37.

[7] Peraturan Menteri Keuangan Republik Indonesia PMK Nomor 113/PMK.05/2012. pp. 1-41

[8] Peraturan Tentang Perjalanan Dinas Dalam Negeri Dan Mekanisme Pembayaran Dalam Rangka Pelaksanaan Annggaran Pendapatan Belanja Negara (APBN). PMK No.190/PMK.05/2012..

\section{(Journal Online Sources style)}

[9] Aginta. Geniusa dan Febriliyan. Samopa. (Vol. 2 No. 2 2013). Pembuatan Sistem Informasi Perjalanan Dinas Kantor Wilayah Direktorat Jenderal Perbendaharaan (SIPD-Kanwil DJPBN). Jurnal Teknik POMITS. [Online]. ISSN: 2337-3539 (2301-9271

Print). pp. A.366 - A.370. Available: http://www.ejurnal.its.ac.id/index.php/teknik/articl e/view/4820/1086

[10] Max. Saleleng dan Agus. Supandi. Soegoto. (Vol 3 No.3 2015). Pengaruh Lingkungan Kerja, Motivasi, Pelatihan dan Kompensasi Terhadap Kinerja Pegawai Pada Dinas Pertanian Kabupaten Sorong Selatan. Jurnal EMBA. [Online]. ISSN: 2303-11. pp. 696-708.

Available:

https://ejournal.unsrat.ac.id/index.php/emba/articl e/view/9656/9240

[11] lis. Oktaviani dan Asri. Mulyani. (Vol. 13 No.1 2016). Pengembangan Aplikasi Surat Perrintah Perjalanan Dinas (SPPD) Beserta Rincian Perjalanan Dinas di Badan Koordinasi Pemerintah dan Pembangunan Wil;ayah IV Kabupaten Garut. Jurnal Algoritma. [Online]. ISSN: 2302-7339. Pp. 58-62. Available: file:///C:/Users/BTI\%20BSI/Downloads/302-453-1PB.pdf

\section{(Thesis or Dissertation style)}

Program Studi Teknik Informatika

Universitas Prima Indonesia (UNPRI) Medan 


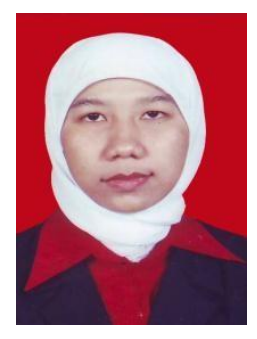

\section{Susan Rachmawati}

Lahir di Jakarta pada tanggal 19 Maret 1981, menyelesaikan S1 dan S2 di Universitas Gunadarma dengan jurusan Akuntansi (S1) dan Sistem Informasi Akuntansi (S2)

Saat ini bekerja di Universitas Bina Sarana Informatika sebagai staf akademik sejak tahun 2013 sampai dengan saat ini.

Beberapa karya ilmiah yang pernah saya tulis diantaranya: Implementasi Data Keuangan Dengan Zahir Accounting Pada PT. Anugerah Analisis Sempurna. Terbit di Jurnal Akuntansi, Ekonomi dan Manajemen Bisnis Vol. 5, No.2, December 2017, 207-273, E-ISSN : 2548-9836; Perancangan Sistem Informasi Penggajian Pada SMK Perintis 1 Depok, Terbit pada Simposium Nasional IImu Pengetahuan dan Teknologi (SIMNASIPTEK) 2017, ISBN: 978-602-61268-4-9; Analisa Perputaran Piutang Dan Perputaran Aktiva tetap Terhadap Profitabilitas Pada PT. Gudang Garam, Tbk terbit di Jurnal Ekonomi \& Ekonomi Syariah (JESYA) Volume 1 Nomor, Juni 2018 dengan nomor E-ISSN : 2599-3410 dan P-ISSN : 2614-3259

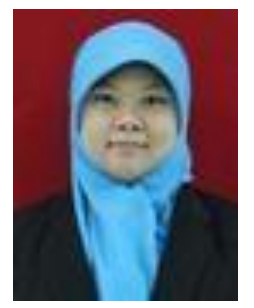

Tri Retnasari

Lahir di Bogor pada tanggal 16 Maret 1987. Telah menyelesaikan S1 STMIK Swadarma dengan jurusan Sistem Informasi dan S2 di STMIK Nusa Mandiri dengan jurusan IImu Komputer.

Saat ini menjadi salah satu dosen tetap di STMIK Nusa Mandiri Jakarta pada program studi Sistem Informasi.
Beberapa tulisan ilmiah yang saya tulis diantaranya: Analisis Penerapan Standart Operational Procedure (SOP) Dalam Pelayanan Kesehatan Berbasis IT Menggunakan Analisa SWOT. Terbit di Jurnal Perspektif Vol. 12 No. 2, 2014. ISSN: 1411-8637; Sistem Manajemen Operasional Pendaftaran Penduduk Pada Dinas Kependudukan Dan Pencatatan Sipil Depok. Terbit di Jurnal Perspektif Vol. 13 No. 1, 2015. ISSN: 1411-8637; Perancangan Sistem Informasi Akuntansi Penerimaan Dan Pengeluaran Kas Berbasis Client Server. Terbit di Jurnal Account (Politeknik Negeri Jakarta) Vol. XVIII No.2 Desember 2017 ISSN 1410-5963.

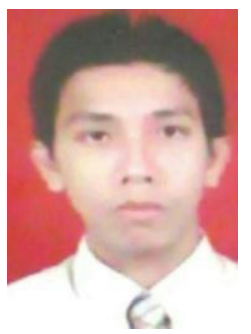

\section{Sunarto}

Lahir di Jakarta tanggal 27 Agustus 1974. Menyelesaikan S1 di Universitas Gunadarma dengan jurusan Manajemen dan S2 di Universitas Gunadarma dengan jurusan Perbankan.

Saat ini merupakan salah satu dosen tetap di Universitas Gunadarma dengan program studi Akuntansi.

Beberapa karya ilmiah yang pernah ditulis diantaranya: Peranan Kepemimpinan Dalam Proses Administrasi dan Manajemen terbit di Jurnal Widya cipta, vol I no. 2 september 2010; Peranan manajemen dalam menciptakan sekolah Efektif nan unggul Widya cipta, vol II No.1Maret 2011.

Program Studi Teknik Informatika 